\title{
THE LEGAL ARRANGEMENT OF WAGE PROTECTION BASED ON THE PRINCIPLE OF LEGAL CERTAINTY
}

\author{
Yetniwati \\ Faculty of Law Universitas Jambi \\ E-mail: yetniwatisamad@yahoo.co.id
}

\begin{abstract}
The wage protection in Indonesian positive law is still not provide legal certainty for the weaker party in the aspect of social economic. In every anniversary of May Day, labor union always demanded to abolish the wage cost, which the Government Regulation No. 78 Year 2015 leanihg to the interests of investors. The principle of legal certainty in the norm of wage protection needs to be realized with respect to: the concept of wage protection, lack of certainty purpose of law, estabished by the competent authorities, accepted by society, legal materials in accordance with the legal hierarchy, the company's obligation to make books wages, and avoid multiple interpretations in legal norms.
\end{abstract}

Keywords: protection of wages, labor, legal certainty.

\begin{abstract}
Abstrak
Pengaturan perlindungan upah dalam hukum positif di Indonesia masih belum sempurna memberikan kepastian hukum untuk melindungan pihak yang lemah sosial ekonominya, setiap peringatan May Day selalu serikat pekerja menuntut hapuskan politik upah murah, PP No. 78 Tahun 2015 lebih pro pada kepentingan investor minta dicabut. Prinsip kepastian hukum dalam norma perlindungan upah perlu diwujudkan dengan memperhatikan: konsep perlindungan upah, adanya kepastian tujuan hukum, dibentuk oleh pejabat yang berwenang, hukum dapat diterima masyarakat, adanya materi hukum yang sesuai dengan hierarki hukum, adanya kewajiban perusahaan membuat buku upah, bahasa hukum yang benar tidak ambigu dalam norma hukumnya.
\end{abstract}

Kata kunci: perlindungan upah, pekerja, kepastian hukum.

Introduction

The role of state and government is becomes protectors of the people or citizens, this role should be able to make regulations for the prosperity of the society. As said by Roscoe Pound "law as a tool of social engineering", which means the function of law as social engineering or to transform society. ${ }^{1}$ The change certainly from unfavorable life to the better life.

Decent wage constitutionally mandated by Article 27 paragraph 2 of 1945 Constitution states that "Every citizen has the right to work and a decent living for humanity", and Article 28D paragraph (1) 1945 Constitution explains

1 Roscoe Pound cited by Firman Muntaqo, "Hukum Sebagai Alat Rekayasa Sosial dalam Praktek Berhukum di Indonesia, Jurnal Hukum Progresif, Vol. 2 No. 1, April 2006, Semarang: Program Doktor Ilmu Hukum Universitas Diponegoro, page. 277 that " Everyone has the right to recognition, security, protection, and fair legal certainty and equal treatment before the law; (2) Everyone has the right to work and to receive remuneration and fair treatment and decent in labor relations". It should be emphasized that wage constitutionally must be fair and reasonable. The right to wage it there after work agreements.

Wages are the rights for worker that have been acquired as a result of their employment relationship. Wages are one of the sources of life for workers. Legally the wage definition specified in Article 1 (30) of Law No. 13 Year 2003 which sets:

Wages are the rights of workers/laborers were accepted and expressed in the form of money as a reward from the employer or employer to worker/laborer assigned 
and paid by an employment agreement, agreements, or the legislation, including allowances for workers/laborers and their families on a work and/or services that have been or will be made.

Dilemmatic wage protection make the workers through the labor unions always do a demonstration in every international labor day which falls on 1 (one) May demanding higher wage or referred to the national minimum wage. ${ }^{2}$ The labor unions demand requesting the revocation of the provisions of Government Regulation No. 78 Year 2015. The strategy of trade unions took to the streets and strikes are a major action to fight for workers aspirations $^{3}$. According to Fuller, said the eight principles that must be fulfilled by law is:

a). A legal system composed of rules, not based on short verdicts on certain rights; b). Regulation was announced to the public; c). Not retroactive, because it will damage the system integration; d). Created in a formulation that is understandable by the public; e). There should be no conflicting regulations; f). Should not require an act exceeds what can be done; g). Not to be frequently altered; h). There must be compatibility between the regulations and the daily implementation ${ }^{4}$.

The opinion of Fuller is a concept of legal certainty from the legislation that can be used as a reference in analyzing the setting of wage protection.

\section{Discussion}

\section{The Concept of Wages Protection in Indonesia} Positive Law Based on the Principle of Legal Certainty.

Legal arangement of wages in Indonesian positive law which contained in Law No. 13 Year 2003 and Government Regulations No. 78 Year

2 Yohanes Suhardin, "Eksistensi Outsourcing dan Kontrak Kerja dar Perspektif HakAsasi Manusia”, Law Journal Pro Justitis, Vol. 27 No. 2, October 2009, Bandung: Law Faculty of Universitas Katolik Parahyangan, page. 194.

3 Ferina Anjarsi, "Strategi Perjuangan Buruh Kota Surabaya dalam Menuntut Kenaikan Upah Minimum 2013 2014", accessed through http:// journal.unair.ac.id/file Pdf/jpm50fdca6783full.pdf accessed on 21-5-2015.

4 Fuller cited by Achmad Ali, 2009, Menguak Teori Hukum (Legal Theory) dan Teori Perdilan (Judicialprudence), Termasuk Interprestasi Undang-undang (Legisprudence). Vol. 1 Pemahaman Awal, Jakarta: Kencana, page 294.
2015 described: first, Vagueness of wages concept. The concept of wages which stated in Article 1 point 30 Law No.13 Year 2003 is derived from the concept that proposed in Draft Law on Labor Development and Protection. In this regulation, the word "work" was increased to workers/laborers and the wages concept are limitedly. According to Article 1 point (30) Law No. 13 Year 2003 in conjunction with Article 1 point (1) Government Regulation No. 78 Year 2015, the wages in the form of money which mean nominal wages, while there are workers in the community get a reward other than money as their wages also receiving something material right on moving objects such as staples, clothing, medicines and others. Facilities provided freely from employers to workers for certain positions, and there are also facilities counted as additional wages. Facilities included in the expenditure or capital expenditure or cost the company still counted. This means that wages can be money and/or combined with innatura. The concept wages contained in the provisions of Article 1, point 30, will be difficult for the forming of legislation against domestic helpers who are now known as the "assistant housekeeping".

Second, The concept of minimum wage is not regulated in Law No.13 Year 2003, the minimum wage provision is found in Article 88 paragraph (2) which states: "The government has set the minimum wage referred to paragraph (3) letter $a$ is based on the need for decent living by taking into account productivity and economic growth". Means the minimum wage is a government policy in protection of workers and also pay attention to employers interests. The definition of "interests" can be interpreted to the needs or requirements that must be fulfilled ${ }^{5}$. The interests of workers is the fulfillment of a decent life. The interests of employers is continuity of business to keep it running well. The concept of a minimum wage is found in the Minister of Manpower Regulation No. 7 of 2013

\footnotetext{
5 Agus Yafli Tawas, "Pengadaan Tanah Untuk Kepentingan Umum (Studi Kasus Pelebaran Jalan Martadinata Paal Dua di Kota Menado)", Law Journal Unsrat, Vol. 1 No. 6, October-Desember 2013, Manado: Faculty of Law Universitas Sam Ratulangi, page 68.
} 
concerning Minimum Wage labor is only intended for beginners who are single. How is the safety net wages for workers who are married and have long working period, there are no settings.

Third, the concept of preventive wages protection is still blurred in Law No.13 Year 2003. Wage protection is a safeguard against wage system based humanely, so that the rights of workers with regard to wages are not eliminated or reduced. Wage protection can be carried out preventive and curative, preventive wage protection in legislation should be able to get the accuracy or certainty laws that govern it. Supposed the wage concept protection already exists clearly in the constitution governing the employment. Adapted to the development objectives of employment under Article 4 as follows: "c. provide protection to workers in welfare; and d. improving the welfare of workers and their families ". Ideally in the explanation of Article 4 defined the term of protection, then Article 88 paragraph (3) states: "Wage policy that protects workers/ laborers include ...", but the explanation of both the laws are not there.

Fourth, the concept of wage components are less clear. In Article 94 Law No.13 Year 2003 which says that: "in terms of wage consists of basic salary and fixed allowance, the amount of the basic wage at least $75 \%$ (seventy five percent) of the total basic salary and fixed allowance". The provision is so vague or ambiguous, it can lead to misinterpretation by entrepreneurs. If the view "that combines all of these extra payments in the sense of minimum wage", it will result in lack of legal certainty to protect workers/ laborers.

Fifth, the provisions of Article 41 Government Regulation No.78 Year 2015 does not provide legal certainty. The provisions of Article 41 Article (2) Government Regulation No.78 Year 2015 states: "The minimum wage as meant paragraph (1) is the lowest monthly wage consist of: a. Wages without benefits; or b. Basic wage including fixed allowances". Naturally, workers would like to get additional allowances as income. The allowance is fixed and there is no fixed. According to Adrian Sutedi:
The fixed allowance consists of many kinds, namely: a. Allowances that are supporting: such as transportation al-lowances; b. Allowances with social functions: health care benefits, old age benefits, allowances expensiveness, wife/ husband allowance, child support, alimony religious days, leave allowance, housing allowance. The socalled social security benefits ${ }^{6}$.

Allowances which are no separate payment to basic wages in terms of minimum wage, this shows the role of benefits as wage supplements do not work.

Sixth, Legalese not provide legal certainty. The title of the legislation which sets minimum wage rates in each province, which would be the nomenclature "Governor Decree" and some are wearing nomenclature "Governor Regulation". The title of the legislation with the nomenclature "Governor Decree" less precise rules used for the title that set the provincial minimum wage. Because nomenclature "Decree" is typically used for official statements aimed to the specific legal subject, individual, whereas the "Regulations" aimed to the general public associated with the norms set. Nomenclature "Governor Regulation" is showing a rule derived from the Governor imposed on its people. From 28 provinces that set minimum wage regulations in Indonesia in 2015, found only 4 provinces (14\%) who use nomenclature "Governor Regulation". Supposed Minister of Manpower and Transmigration issued regulations requiring wear nomenclature "Governor Regulation" to set the lowest wages in every province.

Seventh, the remuneration policy does not provide wage protection specially to workers system outsourcing (outsourcing) and the workers who make the agreement work time (PKWT). Workers who make a certain time work agreement (PKWT). also known labor contract system. Contract labor system, not in wages payment inside of wholesale system, but workers made agreements with employers which time it works in a certain period of time up to 1

\footnotetext{
6 Adrian Sutedi, 2009, Hukum Perburuhan, Jakarta: Sinar Grafika, page 151.
} 
(one) year and can be extended again. The term outsourcing is not found in the Law No.13 Year 2003. According R.Greaver H, said: "outsourcing is regarded as diverting some of company's activities and decision rights to outside provider, where actions is bound in a cooperation contract. ${ }^{7}$ Outsourcing relationship has its own characteristics in the execution of work, thus the reception of irregular wages ${ }^{8}$. The absence of wage protection to this two types work systems will result in the discomfort of the workers who will be unemployed ranges, in terms of both systems more beneficial for companies like: easier to recruit workers without the hassle of job training because it has done an outsourcing company, so that employers focus more on its core business ${ }^{9}$, Employment termination without severance pay. Contract labor system benefits employers, because in the term of employment termination is not required to pay the severance.

Eighth, Government Regulation No. 78 Year 2015 does not consider the needs of decent living (KHL) workers in established Province Minimum Wage annually. The provisions of Article 44 Government Regulation No.78 Year 2015 is more profitable for investor and disregard the need for decent living which predicted to be changed every year. The new formula in determining the minimum wage, which employers can predict and plan the company in the next time. Employers will be able to estimate how wage developments for the next five years. The increment of wages in the next five years is not too large, because it did not consider the needs of decent living of workers per year. Al-

R. Greaver II Cited by Yetniwati, Meriyarni and Suhermi, "Penerapan Norma Perlindungan dalam Perjanjian Kerja Outsourcing (Alih Daya) Pada Perusahaan Perbankan di Kota Jambi”, Law Science journal, Vol. 3 No. 1, September 2012, Jambi: Law faculty of Universitas Jambi, page 81.

8 Surya Nita, “Kendala dan Harapan Pekerja Sistem Outsourcing Dalam Memperoleh Hak Tanpa Diskriminasi di Indonesia", Jurnal Hukum Equality, Vol. 16 No. 2, August 2011, Medan: Law faculty of Universitas Sumatera Utara, page 123.

9 Zainal Asikin cited by Siti Kunarti, “Perjanjian Pemborongan Pekerjaan (Outsoucing) Dalam Hukum Ketenagakerjaan”, Jurnal Dinamika Hukum, Vol.9 No. 1, Januari 2009, Purwokerto: Law Faculty Universitas Jenderal Soedirman, page 71 . though Article 45 Government Regulation No.78 Year 2015 set the government's authority to conduct a review of decent living need once in five years, but the results of that review are not in sync with the provisions of the wage calculation formula as stipulated in Article 44 paragraph (2) Government Regulation No. 78 Year 2015. The purpose of the minimum wage according to Article 1 of ILO Recommendation No. 135 Year 1970 is to overcome poverty and to ensure the satisfaction of the needs of all workers and their families.

Ninth, the Authority Wages Council which provides recommendations to government for determine the Province Minumum Wage also not sync with provisions of Article 44 paragraph (2) Government Regulation No.78 Year 2015. Seen from the provisions of Article 43 and 44 Government Regulation No. 78 Year 2015, the Wages Council has no role for determination of minimum wage each year, because government only through the formulation of Article 44 is sufficient to determine the Province Minimum Wage. Councils as the provisions of Article 45 Government Regulation 78 of 2015, needed in order to conduct a review of the need for decent living for five (5) years.

Tenth, use of the term that improper in Government Regulation No. 78 Year 2015. Provisions Chapter III of the decent income, the nomenclature of "income" generally means the person or family income. Income can be obtained from the employment relationship, and there is also outside the employment relationship. Likewise, the provisions of Article 12 Government Regulation No.78 Year 2015 states: Wages are set by: a. Time Unit; and/ or b. Unit results. The provisions of the law language does not provide legal certainty, since the word "wages set by ..." has a double meaning as "the basis for determining the rates of wages" or "the basis for determining system of remuneration." The basis for determining the wages of which meet the needs of workers and their families a decent life, and balance with the economic condition of companies. While the system of remuneration that is: based on time period, or based on number or unit of work, and there is also a 
mixed system of both systems. The word "necessities of life" in Article 23 paragraph (1) Government Regulation No.78 Year 2015 has a double sense, and the article does not provide legal certainty to guarantee the protection of workers.

Eleventh, component decent living needs as referred to Article 43 paragraph (5) Government Regulation 78 Year 2015 and basic necessities as referred to paragraph (4) be reviewed within a period of five (5) years, in terms price changes of daily needs, often changed in a relatively short period of time. Ideally the review of a living wage is done one time a year, ahead of the enactment of a decent wage would be a minimum, wage More Decent, Very Decent Wages

Twelfth, the provisions of Article 44 of Government Regulation No. 78 Year 2015 concerning minimum wage calculation formula is: $U M_{n}=U M_{t}+\left\{U M_{t} \times\left(\right.\right.$ Inflasi $\left.\left._{t}+\% \Delta \mathrm{PDB}_{\mathrm{t}}\right)\right\}$. Calculation formula of minimum wage is minimum wage plus the current year with minimum wage multiplication for the year by sum of current year the national inflation rate and the growth rate of Gross Domestic Product for the year. This provision is only concerned with economy investor, does not attend to decent living needs that every year changes. And rules are also not in sync with the provisions of Article 43 paragraph (1) Government Regulation No.78 Year 2015 which states that the minimum wage as stipulated in Article 41 is done each year based on the need for decent living by taking into account productivity and economic growth, the provision of Article 44 does not provide legal certainty it should be changed.

\section{The Characteristics of Wage Protection based on the Principle of Legal Certainty}

Based from a good legal theory advanced by Lon Fuller can be used and developed in setting of wages in the future. The principles are described below: first, the existence of clarity in the legal concept of the charge of material law. Wage protection is a safeguard against wage system based humanely, so the rights of workers with regard to wages are not eliminated or reduced. A living wage is a wage that can meet the needs of workers and their families live humanely and in accordance with company's ability conditions level. Safety net wage is a safety framework in order to escape poverty wage of workers.

Second, a legal system consists of regulations, which are arranged according to legal hierarchy that has been regulated by Article 7 Law No.12 Year 2011. Then, under Article 8 Law No. 12 Year 2011, the Company Regulations or Collective Labor Agreement, Working Agreement including the source wage law, as instructed by higher laws. The legal force of legislation should be in conformity with hierarchy. The legal norms below must not conflict with higher legal norms.

Third, the regulations established by competent authority, which must be tailored to legislation type, and includes members of Tripartite as public participation in legislation field employment formation. Fourth, clear legal purposes. The purpose of remuneration in accordance with opening law of 1945 Constitution is to create a fair and prosperous society. It would require government intervention through regulation and supervision for a fair and prosperous society realization, of course this can be realized through legal protection to weaker party. Law protection can be distinguished on preventive protection and repressive ${ }^{10}$. Citizens in general and workers/laborers in particular should receive constitutional rights in decent livelihood form earned from work and remuneration and fair and proper treatment in employment relationship. ${ }^{11}$ Provides protection to weaker party.

Fifth, the Regulation was announced to the public, to make them easier for law enforcement. Sixth, the regulation does not apply retroactively, as it will damage integrity system. Seventh, made in formulation that is understandable by the public

10 M. Husni, "Moral dan Keadilan Sebagai Landasan Penegakan Hukum Yang Responsif", Jurnal Equality, Vol. 11 No. 1 February 2006, Medan: Faculty of Law Universitas Sumatera Utara, page 3.

11 Khairani, "Kedudukan Outsourcing Pasca Putusan Mahkamah Konstitusi Nomor 27/PUU-IX/2011", Jurnal Konstitusi, Vol. 11, No. 4, December 2014, Jakarta: Mahkamah Konstitusi RI, page 815. 
and does not have an ambiguous meaning, the use of a standard term, such as word "Decree" is replaced with the word "regulation" for wages setting, because wages setting are legal norms applicable to the subject of law in general, though applicable for a specific region. Eighth, should not be any conflicting regulations, both vertically or in horizontal. Ninth, it should not be demanding obligations that exceed capabilities. Wage consists of a minimum living wage, decent wages, wages are very feasible as lowest standard tailored to company's ability.

Tenth, not to be frequently modified. Regulations that changed often can result in hard to realize rule of law. Eleventh, the regulation should be accepted by society, and therefore it should be logical rules, to involve stakeholders in norms establishment and contains a sense of justice. Twelfth, existence of company's obligation to make the wage books. Thirteenth, existence of a dispute resolution institutions, both outside court or in court. Fourteenth, the provision of sanctions for violators.

\section{Conclusion}

Based on this analysis we can conclude that: first, the setting of wages in Indonesian positive law is not regulating the concept of wage protection, the concept of wage limiting, the concept of safety net wages do not exist, the concept of a living wage is not yet clear, the concept of minimum wage unconstitutional, still found the language law ambiguous; second, wage setting to realize the legal certainty that is guaranteed legal clarity, then law must have characteristics: legal concepts clarity; the regulations established by appropriate authorities; purpose law clarity; The rules do not apply retroactively; the formulation of common rules understandable; regulation was announced to public; there should be no conflicting regulations; should not require any obligations that extend beyond its ability; not to be frequently altered; that rule can be accepted by society; the existence of dispute resolution institutions; and existence of legal sanctions for violators.
For the sake of legal certainty wage setting in Law No.13 Year 2003 needs to be revised to establish wages protection concept, wage concept. Government Regulation No. 78 Year 2015 also needs to be revised, especially include the concept of wage protection, the concept of a living wage, the wage concept, the concept of a safety net wages in the regulations. Legislators also must pay attention to the characteristics of legal certainty in wage protection setting.

\section{References}

Ali, Achmad. 2009. Menguak Teori Hukum (Legal Theory) dan Teori Perdilan (Judicialprudence). Termasuk Interprestasi Undang-undang (Legisprudence). Vol. 1 Pemahaman Awal. Jakarta: Kencana;

Anjarsi, Ferina. "Strategi Perjuangan Buruh Kota Surabaya dalam Menuntut Kenaikan Upah Minimum 2013-2014". accessed through http://journal.unair.ac.id/file Pdf/jpm50fdca6783full.pdf accessed on may $21^{\text {st }} 2015$.

Husni, M. "Moral dan Keadilan Sebagai Landasan Penegakan Hukum Yang Responsif". Jurnal Equality. Vol 11 No 1. February 2006. Medan: Faculty of Law Universitas Sumatera Utara;

Khairani. "Kedudukan Outsourcing Pasca Putusan Mahkamah Konstitusi Nomor 27/PUUIX/2011". Jurnal Konstitusi. Vol. 11 No. 4. December 2014. Jakarta: Mahkamah Konstitusi RI;

Kunarti, Siti. “Perjanjian Pemborongan Pekerjaan (Outsoucing) Dalam Hukum Ketenagakerjaan”. Jurnal Dinamika Hukum. Vol. 9 No. 1. Januari 2009. Purwokerto: Law Faculty Universitas Jenderal Soedirman;

Muntaqo, Firman. "Hukum Sebagai Alat Rekayasa Sosial Dalam Praktek Berhukum di Indonesia. Jurnal Hukum Progresif. Vol. 2 No. 1. April 2006. Semarang: Program Doktor Ilmu Hukum Universitas Diponegoro;

Nita, Surya. "Kendala dan Harapan Pekerja Sistem Outsourcing Dalam Memperoleh Hak Tanpa Diskriminasi di Indonesia". Jurnal Hukum Equality. Vol. 16 No. 2. August 2011. Medan: Law faculty of Universitas Sumatera Utara; 
Suhardin, Yohanes. "Eksistensi Outsourcing dan Kontrak Kerja dar Perspektif HakAsasi Manusia”. Law Journal Pro Justitis. Vol. 27 No. 2. October 2009. Bandung: Law Faculty of Universitas Katolik Parahyangan;

Sutedi, Adrian. 2009. Hukum Perburuhan. Jakarta: Sinar Grafika;

Tawas, Agus Yafli. “Pengadaan Tanah Untuk Kepentingan Umum (Studi Kasus Pelebaran Jalan Martadinata Paal Dua di Kota Me- nado)". Law Journal Unsrat. Vol. 1 No. 6. October-Desember 2013. Manado: Faculty of Law Universitas Sam Ratulangi;

Yetniwati. Meriyarni and Suhermi. "Penerapan Norma Perlindungan dalam Perjanjian Kerja Outsourcing (Alih Daya) Pada Perusahaan Perbankan di Kota Jambi”. Law Science journal. Vol. 3 No. 1. September 2012. Jambi: Law faculty of Universitas Jambi. 